Vol. 2, No. 1, 2019

\author{
N. E. Stadnytska., I. V. Diakon, I. I. Hubytska, A. O. Mylyanych, V. P. Novikov \\ Lviv Polytechnic National University, \\ Department of Technology of Biologically Active Compounds, Pharmacy and Biotechnology \\ irynadyakon@ukr.net
}

\title{
DEVELOPMENT OF THE SPRAY COMPOSITION BASED ON EXTRACT OF EUCALYPTUS GLOBULUS
}

https://doi.org/10.23939/ctas2019.01.076

One of the main tasks of pharmaceutical technology is the improvement of existing technological processes. For the Ukrainian pharmaceutical market using of non-standardized medicinal raw materials is not a critical factor, but it makes it impossible to enter the world and, in particular, the European market. In view of this, it is proposed to replace the raw material Eucalyptus viminalis used in the preparation of the Chlorophyllipt preparation for the authorized European Pharmacopoeia Eucalyptus globulus and to prove the rationality of this substitution. The resulting extract is introduced into the developed formulation of a spray formulation, which is effective and convenient for use in diseases of the upper respiratory tract, as well as environmentally safe. composition.

Key words: spray, chlorophyllipt, auxiliary substances, extracts, quantitative and qualitative

Н. С. Стадницька, І. В. Дякон, І. І. Губицька, А. О. Милянич, В. П. Новіков

Національний університет “Львівська політехніка", кафедра технології біологічно активних сполук, фармації та біотехнології

\section{РОЗРОБЛЕННЯ СКЛАДУ СПРЕЮ НА ОСНОВІ ЕКСТРАКТУ I3 EVCALYPTUS GLOBULUS}

\begin{abstract}
Одним із основних завдань фармацевтичної технології с вдосконалення існуючих технологічних процесів. Для українського фармацевтичного ринку використання нестандартизованої лікарської сировини не є критичним фактором, проте це робить неможливим вихід на світовий та, зокрема, свропейський ринок. Зважаючи на це, запропоновано замінити сировину Eucalyptus viminalis, яка використовується у виготовленні препарату "Хлорофіліпт", на дозволену Свропейською фармакопесю Eucalyptus globulus та довести раціональність цієї заміни. Одержаний екстракт введено до розробленого складу лікарського препарату у формі спрею, що є ефективним та зручним у використанні у разі захворювань верхніх дихальних шляхів, а також екологічно безпечним.

Ключові слова: спрей, “Хлофіліпт”, допоміжні речовини, екстракти, кількісний та якісний склад.

\section{Introduction}

The trend of modern pharmaceutical development is orientation and approximation to the standards of the European Pharmacopoeia (EF). In particular, it relates to raw materials. The popularity and demand of the population of Ukraine, in connection with the prevalence of diseases of the upper respiratory tract, uses the preparation Chlorophyllipt. The main active ingredient of this product is the Eucalyptus viminalis eucalyptus extract. According to the European Pharmacopoeia,

it is recommended to use the raw material of eucalyptus spherical Eucalyptus globulus for the production of phytopreparations, so the replacement of one type of raw material by another is urgent. On the domestic market, based on the extract of eucalyptus, there are medicines in the form of alcohol and oil solutions, tablets and sprays. The form of spray is very effective and easy to use, but it is manufactured only by the "Experimental Plant" Research Institute of Natural Remedies in Kharkiv.
\end{abstract}


Eucalyptus rod-shaped Eucalyptus viminalis and eucalyptus spherical Eucalyptus globulus are members of the myrtle family. It is evergreen trees, up to 45-55 (70) $\mathrm{m}$ high with a wellbranched root system. The main morphological differences are the shape and size of the leaf blade. For young plants, Eucalyptus globulus is characterized by wide leafy plates about $6-15 \mathrm{~cm}$ in length, covered with gray-blue, wax bloom. The first leaves of young shoots are opposite, seated, oval-oblong, with heart-shaped base, mild-blue; the older leaves are hanging, spirally arranged, lanceolate-sickle-shaped. The leaves of adult plants are narrow, crescent, shiny and dark-green $15-35 \mathrm{~cm}$ in length [1]. The leaves of Eucalyptus viminalis are collected from the old branches of the ball-petiole, broad-lanceolate or long-tailedlanceolate, mostly sickle-curved, thick, leathery, gray-green, 4-27 cm long, $0.5-5 \mathrm{~cm}$ wide. Young branches - Sitting with a rounded base or with a short petiole, elongated-ovoid shaped with a pointed tip, $3.5-11 \mathrm{~cm}$ in length, $0.7-4 \mathrm{~cm}$ in width. The leaves, which have a transitional form, are long-ovoid to lanceolate. Leaves from light green to gray-green, sometimes with a purple shade and a weak syzym bloom, are bare with an integral, even or wavy edge with numerous glands containing essential oils shining in the light.

For the manufacture of phytopreparations, the leaves of both these species are used. Extracts from leaves of eucalyptus act on staphylococci, streptococci, typhoid fever and paratyphs A and B, a stick of disinters, an intestinal stick, purulent and anaerobic pathogens. Eucalyptus has antibacterial, antifungal, antiviral, astringent, hemostatic, antiinflammatory and anesthetic, antioxidant, antidiabetic, and repellent. Eucalyptus medications are used to treat boils and other purulent infections (abscesses, phlegmons, osteomyelitis), ulcers, purulent and fresh wounds, and open fractures; in the case of acute intestinal infections and dyspepsia (vomiting, diarrhea, rgi, and the like), catarrh of the upper respiratory tract (colds, bronchitis, cough), throat infections, stomatitis and gingivitis treatment [2]. Folk medicine uses eucalyptus as an antihelminthic remedy, as well as for the treatment of diphtheria, scarlet fever, and malaria. It should be noted that eucalyptus is contraindicated in pregnancy and high blood pressure.

The leaves of both species include resins, wax, organic acids, tannins, essential oils, phenolic compounds, chlorophyll, and others. Many works are devoted to the study of essential oil components [3]. 72 compounds were detected in Eucalyptus globulus etheric oil, and in the raw material Eucalyptus viminalis there were 64 components. The terpene compounds are represented by cyclic, acyclic and aromatic monoterpenoids and sesquiterpenoids. In Eucalyptus viminalis, scientists have discovered saponins of the triterpene group $[4,5]$. Certain differences in the qualitative composition of the respective groups of biologically active substances are given in Table 1.

Comparative qualitative composition of Eucalyptus viminalis and Eucalyptus globules

\begin{tabular}{|c|c|c|c|c|}
\hline \multirow[b]{2}{*}{ Component } & \multicolumn{2}{|c|}{ Eucalyptus globulus } & \multicolumn{2}{|c|}{ Eucalyptus viminalis } \\
\hline & $\begin{array}{l}\text { Quantitative } \\
\text { content, } \%\end{array}$ & Literary source & $\begin{array}{l}\text { Quantitative } \\
\text { content, } \%\end{array}$ & Literary source \\
\hline 1 & 2 & 3 & 4 & 5 \\
\hline \multirow{2}{*}{ 1,8-cineole } & $58.6-60$ & 6.7 & \multirow{2}{*}{62.0} & \multirow{2}{*}{6} \\
\hline & $85-90$ & 6 & & \\
\hline \multirow{2}{*}{$\alpha$-pinene } & 1,5 & 6 & \multirow{2}{*}{1.7} & \multirow{2}{*}{6} \\
\hline & - & 7 & & \\
\hline \multirow{2}{*}{$\beta$-pinene } & 0.1 & 6 & \multirow{2}{*}{0.4} & \multirow{2}{*}{6} \\
\hline & 0.39 & 7 & & \\
\hline \multirow{2}{*}{ Limonene } & $2-2.2$ & 6 & \multirow{2}{*}{ n. f. } & \multirow{2}{*}{ n. f. } \\
\hline & - & 7 & & \\
\hline terpineol-4 & 0.2 & 6 & - & 6 \\
\hline \multirow{2}{*}{$\alpha$-terpineol } & $1-1.3$ & 6 & \multirow{2}{*}{ n. f. } & \multirow{2}{*}{ n. f. } \\
\hline & - & 8 & & \\
\hline terpinyl acetate & $0.1-0.2$ & 6 & n. f. & n. f. \\
\hline
\end{tabular}


Continuation Table

\begin{tabular}{|c|c|c|c|c|}
\hline 1 & 2 & 3 & 4 & 5 \\
\hline & 2.09 & 7 & & \\
\hline \multirow{2}{*}{$\gamma$-terpinene } & 0.7 & 6 & \multirow{2}{*}{ n. f. } & \multirow{2}{*}{ n. f. } \\
\hline & - & 7 & & \\
\hline \multirow{2}{*}{ cis-ocumen } & 0.1 & 6 & \multirow{2}{*}{ n. f. } & \multirow{2}{*}{ n. f. } \\
\hline & - & 8 & & \\
\hline \multirow{2}{*}{ Linalool } & $0.1-0.2$ & 6 & \multirow{2}{*}{-} & \multirow{2}{*}{6} \\
\hline & - & 7 & & \\
\hline \multirow{2}{*}{ geranyl acetate } & 0.1 & 6 & \multirow{2}{*}{ n. f. } & \multirow{2}{*}{ n. f. } \\
\hline & - & 7 & & \\
\hline Geranium & - & - & - & 6 \\
\hline \multirow{2}{*}{ Mircea } & 0.51 & 6 & \multirow{2}{*}{ n. f. } & \multirow{2}{*}{ n. f. } \\
\hline & - & 7 & & \\
\hline \multirow{2}{*}{$\Delta$-caren } & 0.1 & 6 & n. f. & n. f. \\
\hline & - & 8 & n. f. & n. f. \\
\hline Isofenchon & 2.09 & 6 & n. f. & n. f. \\
\hline \multirow{2}{*}{ Camphene } & $0.1-0.15$ & 6 & - & 6 \\
\hline & 0.51 & 7 & n. f. & n. f. \\
\hline Camphor & n. f. & n. f. & - & 6 \\
\hline \multirow{2}{*}{ Globulol } & $5.9-6.3$ & 6 & n. f. & n. f. \\
\hline & - & 7 & n. f. & n. f. \\
\hline \multirow{2}{*}{ p-tsimen } & 0.34 & 6 & 1.0 & 6 \\
\hline & - & 7 & n. f. & n. f. \\
\hline Cuminal & n. f. & n. f. & - & 6 \\
\hline$\alpha-k u b a n$ & - & 6 & n. f. & n. f. \\
\hline$\alpha-$ Kuoan & - & 7 & n. f. & n. f. \\
\hline$\alpha$-copan & - & 6 & n. f. & n. f. \\
\hline$\alpha$-ourunen & - & 6 & n. f. & n. f. \\
\hline$\alpha$-gurunen & - & 7 & n. f. & n. f. \\
\hline Aromandrene & $6.3-6.5$ & 6 & n. f. & n. f. \\
\hline Aromandrene & - & 7 & n. f. & n. f. \\
\hline allo-aromandrene & $1.6-1.9$ & 6 & n. f. & n. f. \\
\hline allo-aromanarene & - & 7 & n. f. & n. f. \\
\hline$\gamma$-cadenine & - & 6 & n. f. & n. f. \\
\hline$\gamma$-cadenine & - & 7 & n. f. & n. f. \\
\hline Carvone & $0.1-0.2$ & 6 & n. f. & n. f. \\
\hline trans-ninocarveol & $0.2-2.0$ & 6 & n. f. & n. f. \\
\hline trans-pinocarveor & - & 7 & n. f. & n. f. \\
\hline Jedole & $1.4-1.9$ & 6 & n. f. & n. f. \\
\hline Ledole & - & 7 & n. f. & n. f. \\
\hline Isonophenylene & 0.3 & 6 & n. f. & n. f. \\
\hline ursolic acid & n. f. & n. f. & - & 4 \\
\hline $\begin{array}{c}\text { lactone } 11,12- \\
\text { dehydroursulic acid }\end{array}$ & n. f. & n. f. & - & 4 \\
\hline olives acid & n. f. & n. f. & - & 5 \\
\hline gallic acid & - & 9 & n. f. & n. f. \\
\hline elachic acid & - & 9.10 & n. f. & n. f. \\
\hline Eucalyptus & - & 11 & n. f. & n. f. \\
\hline Siderosilin & n. f. & n. f. & - & 4.5 \\
\hline $\begin{array}{l}\text { 5,4-Dioxy-7-methoxy-6,8- } \\
\text { dimethylflavone }\end{array}$ & n. f. & n. f. & - & $12,4,5$ \\
\hline Campferol & n. f. & n. f. & - & $12,4,5$ \\
\hline Quercetin & - & 11 & - & $12,4,5$ \\
\hline Quercetin & n. f. & n. f. & - & 4.5 \\
\hline isoquercitin sodium & n. f. & n. f. & - & 4.5 \\
\hline Routine & n. f. & n. f. & - & $12,4,5$ \\
\hline & (5) & anin & & \\
\hline
\end{tabular}


As we see from the table, Eucalyptus spherical (Eucalyptus globulus) has a more diverse chemical composition. That is why the pharmacological action of the spherical eucalyptus is somewhat wider compared to the eucalyptus rod-shaped [13].

In the pharmaceutical industry from the leaves of eucalyptus, the preparation Chlorophyllipt, which from a chemical point of view is a mixture of chlorophylls and exhibits antibacterial properties and is used in pneumonia, peritonitis, postoperative and postpartum sepsis, burns, complicated pharyngolaringotracheitis, trophic ulcers, erosion of the cervix, endometritis, urethritis, Colt Emit alcohol and oil solutions in vials, in the form of injectable solutions, tablets and sprays.

From the therapeutic point of view, the form of the drug is of great importance. To date, in medical practice, the popularity of sprays is growing. The spray as a drug form has many advantages, the main of which is the high dispersion and easy mobility of particles of the dispersed phase - factors that increase the pharmacological activity of drugs. When inhaling spray, the medicine does not undergo the changes that occur when taken orally. The medicine does not affect gastric and intestinal juices, liver barrier, no drug loss. Sprays also have a number of advantages over injecting solutions, especially the lack of a pain factor.

According to the definitions in the existing publications of the State Pharmacopoeia of Ukraine (DFU) and EF there is a clear separation of the concepts of "aerosol" and "spray" $[14,15]$. Form of aerosol is a solution, suspension or emulsion of active substances that are under pressure of a propellant in an aerosol can (sealed packaging). Spraying is carried out by the valvespray system [14]. Sprays do not contain propellant, the release of the contents occurs due to air pressure generated by a mechanical pump type pump or compressed polymeric packaging. Compared to spray aerosols, the spray is a more coarse disperse system [14, 15]. Aerosols are biphasic (gas and liquid) or three-phase (gas, liquid and solids / liquids) systems. Sprays are monophasic (liquid) or biphasic (liquid and solids or liquids) systems. Two-phase aerosols consist of a solution of the active substance in a liquefied propellant with the addition of solvents that provide the solubility of the active substances. Three-phase aerosols consist of a suspension or emulsion of active substances and propellant [14]. Three-phase aerosols include foam aerosols, which are emulsions containing active substances, surfactants, water or non-aqueous solvents and propellants. If propellant is part of the dispersed phase (emulsion type "oil in water"), during the release of the contents a stable foam is formed.

Substances in the form of aerosols and sprays (solvents, propellants, surfactants, stabilizers, antimicrobial preservatives, antioxidants, etc.) should be allowed for medical use, provide optimum technological characteristics of the dosage form, be compatible with other components of the dosage form and the material packaging.

Substances in the form of aerosols and sprays do not adversely affect the function of the mucous membrane and the respiratory tract [16].

Often, for the treatment of diseases of the respiratory tract are used sprays.

Compared with other drugs by throat pain, sprays have two main advantages:

1. First of all, it is very convenient in practical application the form of a medicinal product;

2. Second, this is the "aim" of the active substance - the drugs are sprayed directly to the affected mucus membrane and form a protective film there, showing anti-inflammatory and bactericidal effects.

\section{The aim of research}

The purpose of our study is to justify the expediency of transition to another type of plant material in the production of chlorophyllipt. In addition, to propose a change of some technological parameters of the production of the condensed extract of Eucalyptus spherical and to develop a new qualitative composition of the spray on its basis.

\section{Materials and methods of research}

The research described below is carried out at a pharmaceutical company, which, in fact, uses the method of statistical planning expertise to develop a new medicinal product. 


\section{Research results and their discussion}

For the Ukrainian market, the use of nonstandardized medicinal raw materials is not a critical factor, but it makes it impossible to enter the world market and, in particular, the European market. In view of this, it was proposed to review the possibility of replacing raw materials and developing Eucalyptus globulus based preparations. To solve this issue in the pharmaceutical company, a study was conducted using the method of statistical planning of the experiment.

The basis of the preparation Chlorophyllipt is a dense extract, obtained from the raw material of Eucalyptus spherical. It should be noted that, in addition to replacing the type of medicinal plant material, non-toxic chloroform and safe ethyl acetate were used during the production of the extract. The function of this organic solvent is the deposition and stabilization of chlorophylls, and it also benefits from other solvents, due to its low cost, low toxicity and a perfectly acceptable odor. In our case, the quality and consistency of the extract have improved, the safety has increased, and the bactericidal effect of the extract remained high. As for the cost of the product, then ethyl acetate is 1.5 times cheaper than chloroform, which makes it possible to cheapen production.

Since the purpose of our study is to develop a spray with the content of the eucalyptus extract, we followed the stages of work characteristic for the development of this dosage form. Spray should be considered as a complex complex of medicinal substances with carrier - the basis [16]. The therapeutic effect of a spray depends on the chemical, structural and mechanical properties of the components (active and auxiliary), their concentration, aggregate state or disperse condition, the basis, technological techniques. The base should provide the desired concentration of the dosage form, it is easy to release the active substances, be compatible with the components of the spray. The main requirement is to be biologically indifferent $[17,18]$.

In this regard, at the initial stage of the development of the spray composition, special attention was paid to optimal dosage of a complex extract from the raw material of eucalyptus, as well as the composition of the spray, taking into account its local irritant action. It was determined that the optimal concentration of alcoholic extract of Eucalyptus spherical is $2 \mathrm{mg} / \mathrm{ml}$. It is this amount of active substance (biologically active substances) that provides bactericidal action and antibacterial activity of the drug.

Antibacterial activity was determined by microbiological method using 2-fold serial dilutions in a soybean casein broth with Staphylococcus aureus test microorganism (25.000 microbial cells per $\mathrm{ml}$ ). To test, 3 rows of tubes were taken in 4 in each. The results of the test were recorded after incubation at a temperature of $(32.5 \pm 2.5){ }^{\circ} \mathrm{C}$ for 48 hours. The antibacterial activity of the test sample was evaluated visually. The results are presented in Table 2.

In the pharmaceutical development of any drug, the use of properly selected auxiliary substances is proposed in order to improve the pharmaco-technological parameters of the medicinal product (LD), to achieve the desired release profile of the active substance and to achieve the proper stability of the drug, as well as to ensure the patent purity of the drug.

Table 2

\section{Antibacterial activity of extract from Eucalyptus globulus}

\begin{tabular}{|l|c|c|c|c|}
\hline \multicolumn{2}{|c|}{ Investigated sample } & \multicolumn{5}{c|}{ Concentration, mkg / ml } \\
\cline { 2 - 5 } & 50 & 25 & 12.5 & 6.25 \\
\hline Extract Evcaliptus globulus & + & + & + & + \\
\hline Spray from Evcaliptus globulus & + & + & - & - \\
\hline
\end{tabular}

When selecting excipients for the studied spray, the pharmaco-technological characteristics, which should be characterized by the product of the chosen type - product dosage, particle size, etc., were taken into account. Also, indicators of quality and other necessary characteristics of similar products of the pharmaceutical market of Ukraine were taken into account.

Attention should be paid to excipients that actively influence the release of active pharmaceutical ingredients of spray (speed, completeness), bioavailability, preservation or enhance- 
ment of activity (stabilizers, preservatives and emulsifiers). Especially when creating therapeutic systems with controlled release and targeted delivery of active substances to certain organs.

The optimal use of auxiliary substances with their diverse functional capabilities in the production of sprays becomes possible only when conducting extensive experimental and biopharmaceutical research to form evidence base of the optimal composition, production and quality control methods of the pharmaceutical system (at the phases of pharmaceutical development). Confirmation of the correctness of such an approach can be the introduction into the production and medical practice of combined medications in the form of a spray.
It is important to emphasize that the production uses auxiliary substances that are authorized by the Ministry of Health of Ukraine. Their quality is regulated by the State Pharmacopoeia of Ukraine, analytical and normative documentation or the Quality Guidelines "Substances" (42-3.6: 2004).

Since chlorophyll content - a thick extract is insoluble in water, it is recommended to use organic solvents and emulsifiers. There are several options for tested excipients, and there are risk factors for the final product when used. Table 3 shows optimal solvents in a certain combination with an emulsifier. $X^{1}$ and $X^{2}$ are parameters that will change when assessing the risks of selecting the optimal components of the product; $a^{1}, a^{2}, b^{1}$, $b^{2}$ are possible combinations of solvent and emulsifier in the finished product.

Table 3

Selection and coding of the choice of auxiliary substances

\begin{tabular}{|c|c|c|c|c|}
\hline \multirow{2}{*}{ Factors } & \multicolumn{4}{|c|}{ Variables } \\
\hline & $\mathrm{X}^{1}$ & Abbreviation & $\mathrm{X}^{2}$ & Abbreviation \\
\hline \multirow[t]{3}{*}{ Solvent system } & Water & \multirow[t]{3}{*}{$a^{1}$} & Water & \multirow[t]{3}{*}{$\mathrm{a}^{2}$} \\
\hline & Alcohol & & Alcohol & \\
\hline & Glycerin & & Propylene glycol & \\
\hline Emulsifier & Twin -80 & $b^{1}$ & Creamophore & $\mathrm{b}^{2}$ \\
\hline
\end{tabular}

In addition to the choice of auxiliary substances, the critical factor in the creation of any medicinal product is to ensure the quality of the product and the reproduction of its organoleptic properties. Particular attention is paid to the solubility of the components $\left(\mathrm{y}^{1}\right)$, the transparencyof the product $\left(\mathrm{y}^{2}\right)$ and its antimicrobial activity $\left(\mathrm{y}^{3}\right)$.

In the course of work, four variants of the spray composition on the basis of
Eucalyptus globulus eucalyptus extract were investigated.

The obtained products were tested according to the above criteria, the results are presented in Table 5.

Solubility, transparency and antibacterial activity are critical parameters, that must be included in the specification of the drug, based on the extract of eucalyptus.

Table 4

The variants of the spray composition based on the extract of Eucalyptus globules

\begin{tabular}{|l|c|c|c|c|}
\hline \multirow{2}{*}{ Components } & \multicolumn{4}{|c|}{ Amount, ml } \\
\cline { 2 - 5 } & $\begin{array}{c}\text { Composition } \\
\left(\mathrm{a}^{1}{ }_{\mathrm{B}}{ }^{1}\right)\end{array}$ & $\begin{array}{c}\text { Composition } 2 \\
\left(\mathrm{a}^{1} \mathrm{~B}^{2}\right)\end{array}$ & $\begin{array}{c}\text { Composition } 3 \\
\left(\mathrm{a}^{2} \mathrm{~B}^{1}\right)\end{array}$ & $\begin{array}{c}\text { Composition } 4 \\
\left(\mathrm{a}^{2}{ }^{2}\right)\end{array}$ \\
\hline $\begin{array}{l}\text { Extract of Eucalyptus } \\
\text { globulus }\end{array}$ & 0.625 & 0.625 & 0.625 & 0.625 \\
\hline Glycerin & 20.85 & 20.85 & - & - \\
\hline Ethanol & 7.5 & 7.5 & 7.5 & 7,5 \\
\hline Propylene glycol & - & - & 20.85 & up to 250.00 \\
\hline Water purified & up to 250.00 & up to 250.00 & up to 250.00 & - \\
\hline Twin-80 & 0.625 & - & 0.625 & 0.625 \\
\hline Cremophore & - & 0.625 & - & \\
\hline
\end{tabular}


Characteristics of the parameters of cooked spray

\begin{tabular}{|c|c|c|c|c|c|}
\hline \multirow{2}{*}{$\begin{array}{c}\text { Parameter of } \\
\text { optimization }\end{array}$} & \multirow{2}{*}{$\begin{array}{c}\text { Parameter } \\
\text { characteristic }\end{array}$} & Composition 1 & Composition 2 & Composition 3 & Composition 4 \\
\cline { 3 - 6 } & $\begin{array}{c}\text { Solubility of } \\
\text { components }\end{array}$ & + & + & + & + \\
\hline$y^{1}$ & Transparency & - & + & + & + \\
\hline$y^{3}$ & Antimicrobial activity & + & - & + & - \\
\hline
\end{tabular}

As we can see from the table presented, from the proposed and investigated options for the development of a new drug based on Eucalyptus globulus, only the third variant of the composition of the spray meets all the parameters, showing an antimicrobial effect, which makes it possible to conclude that the proposed components are qualitative and effective.

\section{Conclusions}

The study substantiated the feasibility of replacing the raw material Eucalyptus viminalis with the European Pharmacopoeia approved by Eucalyptus globulus, which is used in the production of Chlorophyllipt. In addition, it was proposed to change the technological parameters of the production of the condensed extract of Eucalyptus globulus and to develop a new qualitative composition of the spray on its basis.

\section{References}

1. WHO Monographs on Selected Medicinal Plants. (2004). A World Health Organization resource.

2. Grodzinskiy A. M. (1990). Medicinal Plants: Encyclopedic Handbook. Kyiv: Heads edit URE.

3. Kumar H. D., Laxmidhar S. A. (2011). Review on phytochemical and pharmacological of Eucalyptus Globulus. International Journal of Research in Ayurveda and Pharmacy, No. 5 pp. 15271530 ref.32.

4. Савина А. А. (1998). Лактон 11,12дигидроурсаловой кислоты из листьев Eucalyptus viminalis. Химия природ. соедин., № 2, 295-296.

5. Савина А. А. (1983). Маслиновая кислота із листьев E. viminalis. Химия природ. соедин., № 1, 113-114.
6. Сур С. В. (1993). Состав эфирных масел лекарственных растений. Растительные ресурсы, №1 (29), 109-110.

7. Renedof O., Otero J., Mira J. (2000). Oile essentielle de Eucalyptus globulus L. de Contabrie. Variation fn cours de la distillation. Plant. med. et phetother., No. 1(24), 31-38.

8. Martines Migdalia (2006). Estudio preliminar de los aceites esenciales de Evcalyptus introducides en la region de Topes de Callantes. Rev. cub. Farm., No. 2, 159-168.

9. Муравьева Д. И. (2003). Тропические и субтропические лекарственные растения. Москва, Медицина.

10. Jong-Pyung K., In-Kyoung L., Bong-Sik Y. (2001). Ellagic acid rhamnosides from the stem bark of Eucalyptus globulus. Phytochemistry: The International Journal of Plant Biochemisery, No. 4(57), 587-591.

11. Kenji O., Hideyuki Y., Hiroshi M. (2006). Eucalyptone from Eucalyptus globulus. Phytochemistry: The International Journal of Plant Biochemisery, No. 1(40), 183-184.

12. Джанашия Н. М. (2007). Флавоноловые гликозиды. Eucalyptus viminalis. Химия природ. соедин, No. 4, 764-765.

13. Olayinka A. J., Olawumi O. O., Olalekan A. M., Abimbola A. S., Idiat I. D., Theophilus O. A. (2012). Chemical composition, antioxidant, and cytotoxic effects of Eucalyptus Globulus grown in north-central Nigeria. J. Nat Prod Plant Resour, No. 2(1): 1-8.

14. ДФУ, Доповнення 1 (2008). Харків.

15. European Pharmacopoeia, 7 th. ed. (2009). Strasbourg: Council of Europe.

16. Chueshov V. I., Gladui E. V., Sayyko I. V. (2013). Technology of medicines for industrial production in two parts. Part 2: Textbook, Kharkiv.

17. The European Medicines Agency (EMA). (2010).

18. Кошовий О. М. (2004). Амінокислотний та мінеральний склад екстрактів із листя евкаліпту. Фармаком, o. 4, 57-61. 